\title{
Note
}

\section{Length-weight relationship of dominant fish species of two medium reservoirs of Uttarakhand, India}

\author{
ASHUTOSH MISHRA ${ }^{1}$, S. K. CHAKRABORTY ${ }^{2}$, A. K. JAISWAR ${ }^{2}$ and A. P. SHARMA ${ }^{3}$ \\ ${ }^{1}$ College of Fisheries, G. B. Pant University of Agriculture and Technology, Pantnagar - 263145 \\ Uttarakhand, India \\ ${ }^{2}$ ICAR-Central Institute of Fisheries Education, Versova, Andheri (W), Mumbai - 400 061, Maharashtra, India \\ ${ }^{3}$ ICAR-Central Inland Fisheries Research Institute, Barrackpore, Kolkata, West Bengal, India \\ e-mail: ashutosh36in@yahoo.co.in
}

\begin{abstract}
Length-weight relationship of dominant fish species namely, Labeo rohita, Labeo gonius, Cirrhinus mrigala and Wallago attu of two medium reservoirs viz., Dhaura and Baigul located in Tarai region of Uttarakhand were studied. There was a positive correlation between length and weight among these fishes. The values of coefficient of determination $\left(\mathrm{R}^{2}\right)$ and slope (b) in the length-weight relationship ranged from 0.7994 to 0.9591 and from 2.3089 to 3.0627 respectively for fishes from Dhaura Reservoir and from 0.7694 to 0.9843 and from 2.4272 to 3.2286 respectively for fishes of Baigul Reservoir. The condition of the fishes of Baigul Reservoir was better than Dhaura in relation to length and weight.
\end{abstract}

Keywords: Cirrhinus mrigala, Coefficient of determination, Condition factor, Labeo rohita, Labeo gonius, Medium reservoirs, Scatter diagram, Uttarakhand, Wallago attu

Dhaura and Baigul, two medium reservoirs covering a total area of 1280 and 2995 ha respectively, provide significant fish catch in Tarai region and are considered as important fish bowls of Uttarakhand. Length-weight data of the fishes are useful standard outputs of sampling programs (Morato et al., 2001). These data are needed to estimate growth rates, length and age structures and other important parameters of fish population dynamics (Kolher et al., 1995). Length-weight relationships are also useful for comparing life history and morphological aspects of populations inhabiting different regions (Goncalves et al., 1997; Stergiou and Moutopoulos, 2001). One of the most commonly used analysis of fisheries data is length-weight relationship (Mendes et al., 2004). Despite the utility of length-weight relationship in fisheries and importance of Dhaura and Baigul reservoirs for Uttarakhand fisheries, information about the length-weight relationship of fish species from these reservoirs is limited.

In the present study, four dominant fish species of Dhaura and Baigul reservoirs viz., Labeo rohita, Labeo gonius, Cirrhinus mrigala and Wallago attu were studied with respect to their length-weight relationships. Dhaura and Baigul reservoirs, situated in the Tarai region (sub-mountain tract) of Uttarakhand were selected for the present study as these are medium sized, productive and approachable. Dhaura Reservoir ( $28^{\circ} 53^{\prime}$ N; $79^{\circ} 34^{\prime}$ E) is located at $200 \mathrm{~m}$ mean sea level (MSL) whereas Baigul
Reservoir $\left(28^{\circ} 56^{\prime} \mathrm{N} ; 79^{\circ} 40^{\prime} \mathrm{E}\right)$ is situated at $211 \mathrm{~m} \mathrm{MSL}$ (Fig. 1). Fishes were sampled from gillnet (size $50 \times 2 \mathrm{~m}$, mesh size 1.5 to $7.5 \mathrm{~cm}$ ) catch, monthly once from June 2006 to May 2007, based on a random sampling method, covering the total area of the reservoirs up to $4 \mathrm{~m}$ depth.

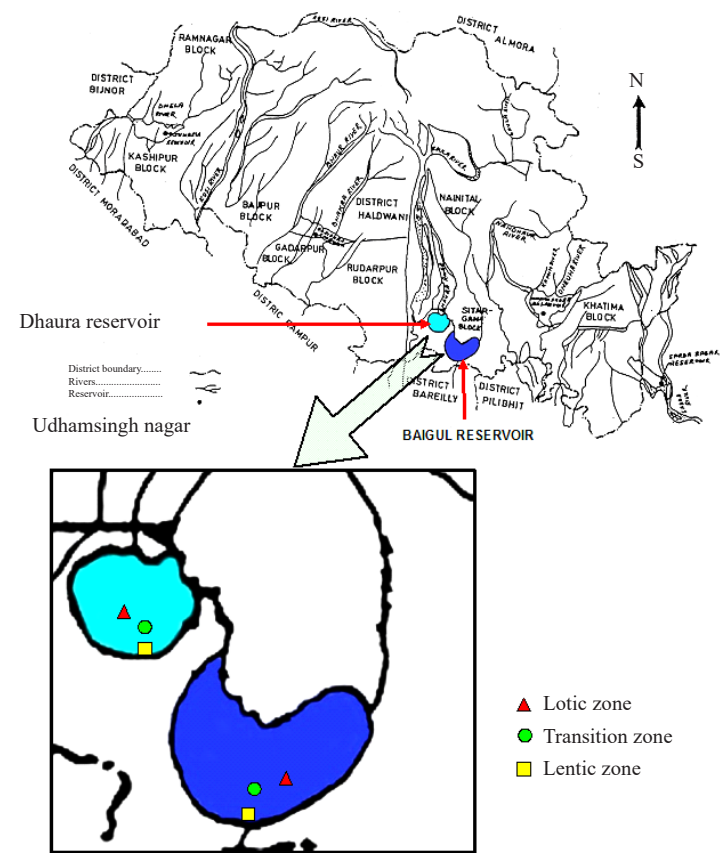

Fig. 1. Map showing study sites in the selected reservoirs 
A toal of 616 fishes were measured for total length and body weight to the nearest $\mathrm{mm}$ and $\mathrm{g}$ respectively.

The length-weight relationships were estimated from the allometric formula, $W=a L^{b}$ given by Le Cren (1951), where $\mathrm{W}$ is total body weight $(\mathrm{g}), \mathrm{L}$ the total length $(\mathrm{mm})$, $a$ and $b$ are coefficients of the functional regression between W and L (Ricker, 1973). The length-weight relationship was calculated separately and a scatter diagram was plotted for each species. The coefficient of determination, $a$ (intercept) and $b$ (regression coefficient) values were calculated following the methods described by Snedecor and Cochran (1967). The regression coefficient b was tested against the isometric value of 3 using the Student's t-test (Snedecor and Cochran, 1967) at a significance level of $5 \%$.

The length-weight relationship of 4 dominant fish species of Dhaura and Baigul reservoirs was studied. The estimates of coefficient of determination $\left(\mathrm{R}^{2}\right), a$ (intercept) and $b$ (regression coefficient) of fishes from Dhaura and Baigul reservoirs are given in Table 1 and 2 respectively. Fig. 2 (a-d) and 3 (a-d) depicts the length-weight relationship of the four species of fishes from Dhaura and Baigul reservoirs respectively. The sample sizes ranged

Table 1. Regression equation of length-weight relationship of selected fishes of Dhaura Reservoir

\begin{tabular}{|c|c|c|c|c|c|}
\hline Species & No. of fishes & Weight range $(\mathrm{g})$ & Length range (mm) & Regression equation & $\mathrm{R}^{2}$ \\
\hline Labeo rohita & 66 & $200-4000$ & $245-700$ & $\mathrm{Y}=1 \mathrm{E}-0.5 \mathrm{X}^{2.9948}$ & 0.9531 \\
\hline Labeo gonius & 117 & $20-850$ & $150-420$ & $Y=2 E-05 X^{2.9016}$ & 0.8312 \\
\hline Cirrhinus mrigala & 89 & $70-3000$ & $210-620$ & $Y=7 E-06 X^{3.0627}$ & 0.9591 \\
\hline Wallago attu & 60 & $20-2750$ & $125-835$ & $Y=0.0003 X^{2.3089}$ & 0.7994 \\
\hline
\end{tabular}

Table 2. Regression equation of length-weight relationship of selected fishes of Baigul Reservoir

\begin{tabular}{llllll}
\hline Species & Number of fishes & Weight range $(\mathrm{g})$ & Length range $(\mathrm{mm})$ & Regression equation & $\mathrm{R}^{2}$ \\
\hline Labeo rohita & 52 & $150-5000$ & $225-770$ & $\mathrm{Y}=5 \mathrm{E}-06 \mathrm{X}^{3.1441}$ & 0.9843 \\
Labeo gonius & 107 & $125-1250$ & $220-465$ & $\mathrm{Y}=3 \mathrm{E}-06 \mathrm{X}^{3.2286}$ & 0.9603 \\
Cirrhinus mrigala & 77 & $350-4000$ & $270-760$ & $\mathrm{Y}=0.0004 \mathrm{X}^{2.4272}$ & 0.7694 \\
Wallago attu & 48 & $90-5000$ & $192-1002$ & $\mathrm{Y}=3 \mathrm{E}-05 \mathrm{X}^{2.7637}$ & 0.9213 \\
\hline
\end{tabular}

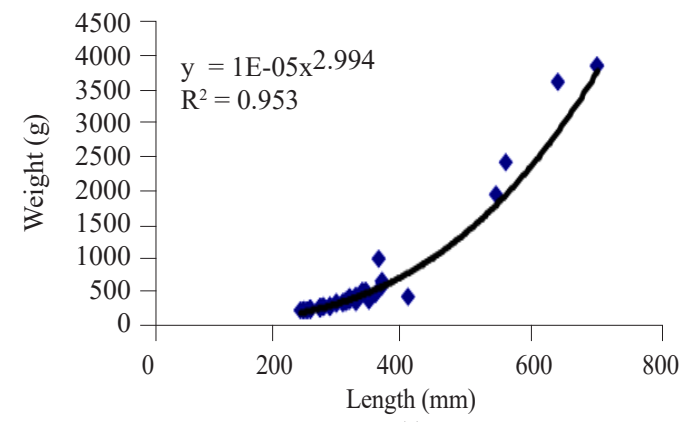

(a)

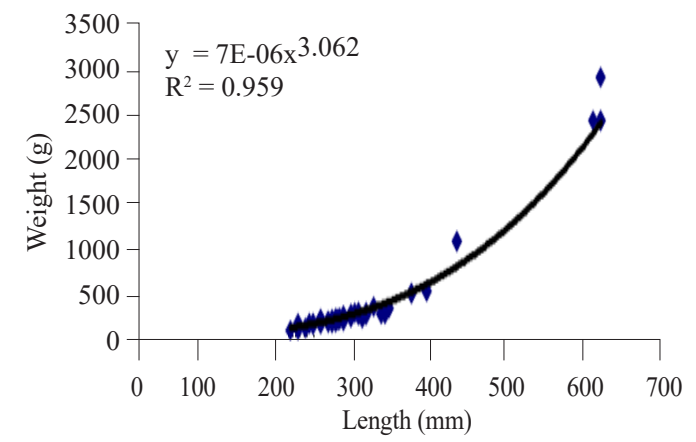

(c)

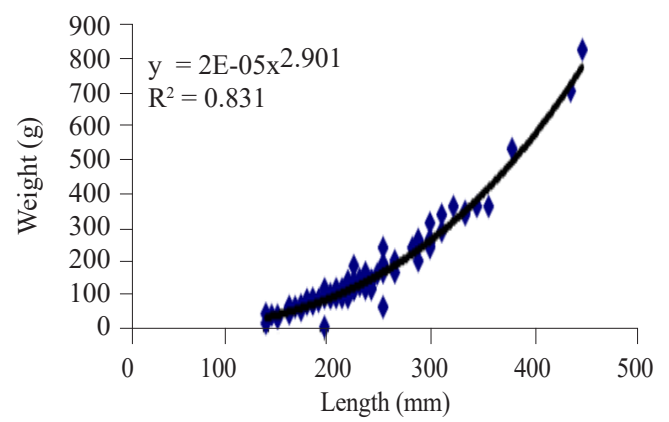

(b)

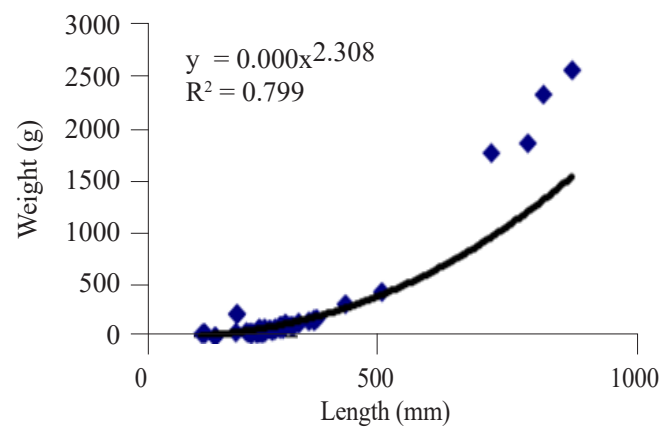

(d)

Fig. 2. Length-weight relationship of fishes in Dhaura Reservoir. (a) Labeo rohita, (b) Labeo gonius, (c) Cirrhinus mrigala, (d) Wallago attu 


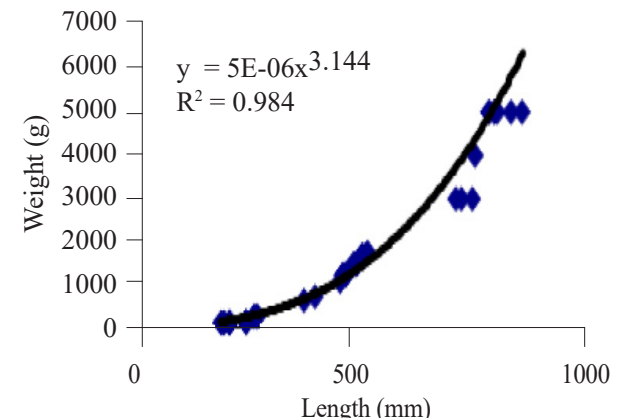

(a)

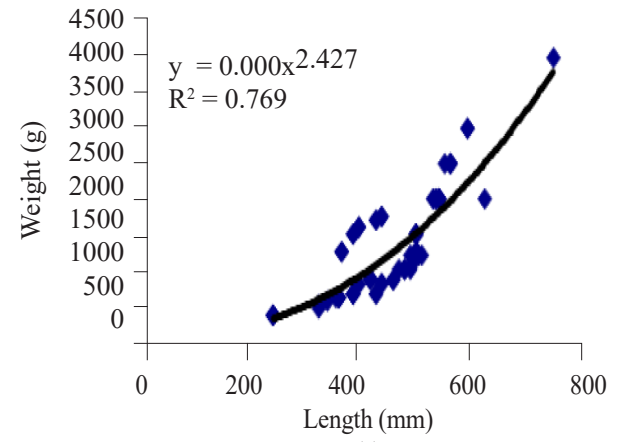

(c)

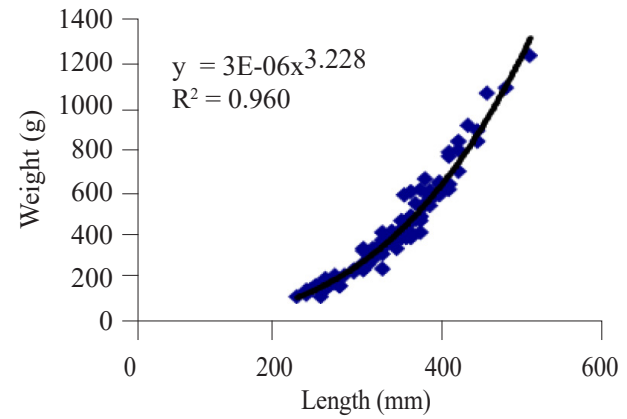

(b)

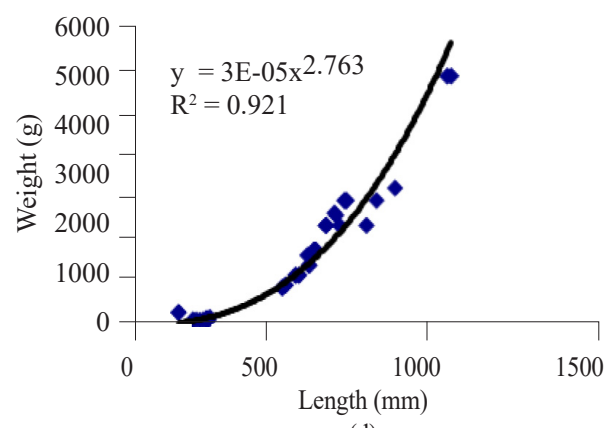

(d)

Weight $(\mathrm{g})$, — Power (weight, g)

Fig. 3. Length-weight relationship of fishes in Baigul Reservoir. (a) Labeo rohita, (b) Labeo gonius, (c) Cirrhinus mrigala, (d) Wallago attu

from 60 individuals for $W$. attu to 117 for L. gonius in Dhaura and from 48 for $W$. attu to 107 for L. gonius in Baigul reservoirs. The coefficient of determination $\left(\mathrm{R}^{2}\right)$ ranged from 0.7994 for $W$. attu to 0.9591 for $C$. mrigala in Dhaura and from 0.7694 for C. mrigala to 0.9843 for L. rohita in Baigul, respectively. The values of $\mathrm{b}$ ranged from 2.3089 for W. attu to 3.0627 for C. mrigala in Dhaura and from 2.4272 for C. mrigala to 3.2286 for L. gonius in Baigul. A high degree of positive correlation between total length and weight of all the four fish species was evident from the high values of coefficient of determination. The $\mathrm{p}$ values of the regression coefficient $b$ of $L$. rohita, L. gonius and C. mrigala of Dhaura Reservoir were less than 0.05 indicating significant difference (t-test, $\mathrm{p}<0.05$ ) from isometric growth. However, isometric growth was indicated for L. rohita, L. gonius and W. attu of Baigul Reservoir (t-test, $\mathrm{p}>0.05$ ). Most of the estimated values of $b$ obtained in the present investigation show a similar trend with those of Gulam and Misned (2015) in Padma River; Sani et al. (2010) in the tributaries of Ganga and Yamuna; Pet et al. (1996) in Sri Lankan reservoirs and by Ramakrishniah (1988) in the Nagarjun Sagar Reservoir. The growth of $W$. attu of Dhaura and C. mrigala of Baigul were negatively allometric $(b<3)$. These fishes do not grow in proportion to the length but the increase in weight occurs with much smaller increments with increase in length. This indicates that the population of these fishes are not growing isometrically and is likely to have less conditioning (Froese, 2006). The $b$ values of $L$. rohita, L. gonius and W. attu of Baigul Reservoir (3.144, 3.228 and 2.764, respectively) were found to be higher than those of Dhaura Reservoir (2.995, 2.902 and 2.309, respectively) showing a better isometric relationship in length and weight. The higher values of $b$ for L. rohita, $L$. gonius and $W$. attu of Baigul Reservoir may be due to the dominance of juveniles and incomplete coverage of the known size range. The same finding has also been reported by Gulam and Misned (2015) for the fishes of Padma River. Also, the Baigul Reservoir is dominated with luxuriant growth of aquatic vegetation compared to Dhaura. These aquatic plants are restricted to shallow areas and are important habitats for fish because they increase spatial heterogeneity and feeding resource availability (Oliveira et al., 2004). Differences in the slopes of the length-weight estimates for the same species in the two reservoirs could be attributed to different environmental conditions or developmental state of the fish (Le Cren, 1951). The better condition of fishes in Baigul Reservoir could be attributed to stable water quality parameters as it is situated near to the Shivalik hills, less effect of wind action than Dhaura, sufficient water volume throughout the year due to high rainfall, higher density of fast growing 
older fishes and higher water depth than Dhaura. The availability of sufficient nutrients in Baigul leads to increase in plankton production. The poor condition of fishes in Dhaura Reservoir may be attributed to variations in water quality parameters, fluctuation in water volume, high density of weed fishes, regular harvest of young fishes before their minimum size of maturity and lesser water depth due to high siltation rate. The higher $b$ values of C. mrigala of Dhaura than the Baigul represents a better condition of this fish in Dhaura as compared to Baigul. The results in the present study are comparable to those reported by Rawat (1991) for Tumaria Reservoir and by Deorari (1993) for Dhaura Reservoir of Uttarakhand.

The length-weight parameters presented here may be of considerable use in ongoing stock assessment studies in reservoir fisheries.

\section{References}

Deorari, B. P. 1993. Productive potential of a manmade reservoir of Tarai of Uttar Pradesh with particular reference to fish fauna. Ph. D. Thesis, Rohilkhand University, Bareilly, Uttar Pradesh, India, 291 pp.

Froese, R. 2006. Cube law, condition factor and weight-length relationships: history, meta-analysis and recommendations. J. Appl. Ichthyol., 22: 241-253.

Goncalves, J. M. S., Bentes, L., Lino, P. G., Ribeiro, J., Canario, A. V. M. and Erzinin, K. 1997. Weight-length relationships for selected fish species of small scale demersal fisheries of the south and south-west coast of Portugal. Fish. Res., 30: $253-256$.

Gulam Mortuza, M. and Fahad, A. Al-Misned 2015. Lengthweight relationships of twelve fishes from the river Padma near Rajshahi City, Bangladesh. Fish. Aquac. J., 6: 112-113.

Kolher, N., Casey, J. and Turner, P. 1995. Length-weight relationships for 13 species of sharks from the Western North Atlantic. Fish. Bull. NOAA, 93: 412-418.

Le Cren, C. D. 1951. The length-weight relationship and seasonal cycle in gonad weight and condition in perch (Perca fluviatilis). J. Anim. Ecol., 20: 201-219.
Mendes, B., Fonseca, P. and Campos, A. 2004. Weight-length relationships for 46 fish species of the Portugeuese West coast. J. Appl. Ichthyol., 20: 355-361.

Morato, T. P., Afonso, P., Lourinho, P., Barreiros, J. P., Santos, R. S. and Nash, R. D. M. 2001. Length-weight relationships for 21 coastal fish species of the Azores, North-Eastern Atlantic. Fish. Res., 50: 297-302.

Oliveira, E. F., Goulart, E. and Minte-Vera, C. V. 2004. Fish diversity along spatial gradients in the Itaipu Reservoir, Parana, Brazil. Braz. J. Biol., 64(30): 1-16.

Pet, J. S., Gevers, G. J. M., Van Densen, W. L. T. and Vihverberg, J. 1996. Management options for a more complete utilisation of the biological fish production in Sri Lankan reservoirs. Ecol. Freshw. Fish., 4: 1-14.

Ramakrishniah, M. 1988. Age, growth and fisheries of Mystus aor (Hamilton) from Nagarjunsagar Reservoir. In: Mohan Joseph, M. (Eds.), Proceedings of the First Indian Fisheries Forum, Asian Fisheries Society Indian Branch, Mangalore, India, p. 185-198.

Rawat, H. S. 1991. Studies on the limnology and fisheries of Tumaria Reservoir (Nainital). Ph. D. Thesis, Kumaun University, Nainital, India, 188 pp.

Ricker, W. E. 1973. Linear regression in fishery research. J. Fish. Res. Board Can., 30: 409-434.

Sani, R., Gupta, B. K., Sakar, U. K., Pandey, A. and Dubey, V. K. 2010. Length-weight relationships of 14 Indian freshwater fish species from the Betwa (Yamuna River tributary) and Gomti (Ganga River tributary) rivers. J. Appl. Ichthyol., 26: $456-459$

Snedecor, G. W. and Cochran, G. 1967. Statistical methods, $6^{\text {th }}$ edn. Oxford and IBH Publishing Co., New Delhi, 593 pp.

Stergiou, K. I. and Moutopoulos, D. K. 2001. A review of length-weight relationships of fishes from Greek marine waters. NAGA, ICLARM Quart., 24(1-2): 23-39. 